\title{
Monitoring the green turtle population Chelonia mydas (Linné, 1758) in the coastal region of Campo Ma'an national park (South Cameroon)
}

\author{
Angoni HYACINTHE ${ }^{1 *}$, Amougou AKOA ${ }^{1}$, Jacques FRETEY ${ }^{2}$ and Angela FORMIA ${ }^{3}$ \\ ${ }^{1}$ University of Yaounde I, Faculty of Science, Dept.of BPV, BP: 812 Cameroon. \\ ${ }^{b}$ UICN-France, Laboratoire d'Evolution MNHNP, 36 rue G. Saint-Hilaire,Paris, Ile-de-France 75005 \\ ${ }^{3}$ University of Florence, via Romana 17, 50125 Florence, Italy. \\ *Corresponding author, E-mail: angonih@yahoo.fr, Tel: 99194900
}

\begin{abstract}
In Cameroon, marine turtles are usually captured accidentally in fishing nets. Among the species captured, the green turtles are captured through out the year but they lay eggs on the coast irregularly. To carry out study on Chelonia mydas, data on the identification of 77 Sea Turtles was collected from 1998 to 2005 using sea turtle carapace on sale along the road and in all households of the 10 villages between $75 \mathrm{Km}$ from of Kribi and Campo. The capture and recapture method was used with the participation of fishermen and the regional marine turtles protection team. To identify and measure live or dead turtles and to tag with MONEL flipper tags, all live and untagged turtles caught in the nets of local fishermen, we were present when fishermen returned from fishing trips. Turtles captured having tag numbers were registered by their tag numbers. The team also carried out monitoring of nests along the $15 \mathrm{~km}$ beach between Mbendji and Bekolobe for four years (1998 to 2002). 134 turtles were tagged and released in the wild. A total of 209 green turtles (Chelonia mydas) were identified and measured along the coastal zone of the Campo Ma'an national park. The average curved carapace length was $50,29 \mathrm{~cm}$ and the width was $49,99 \mathrm{~cm}$. In the small classes of curved carapace length (3040) $\mathrm{cm}$, the animals increase till a maximum of class length $(45-50) \mathrm{cm}$ and the number decreases progressively and stops when the values of the class length are $70-75 \mathrm{~cm}$. Among the tagged animals, 18 were recaptured approximately $3 \mathrm{~km}$ from the release site, thus indicating relative sedentary juvenile green turtles around the Campo Ma'an coastline. Only one sea turtle migrated into the Equatorial Guinea coastline after two years.

(C) 2012 International Formulae Group. All rights reserved.
\end{abstract}

Keywords: Chelonia mydas, tagged turtle, feeding habitat, recaptured turtle

\section{INTRODUCTION}

In the Cameroon coastline are found the olive redley (Lepidochelys olivacea), leaderback (Dermochelys coriacea), hawsbill (Eretmochelys imbricata) and green (Chelonia mydas) sea turtles.

Lepidochelys olivacea and Dermochelys coriacea nest on the Campo Ma'an beaches from October to March, while
Eretmochelys imbricata and Chelonia mydas are only captured in fishing nets (Angoni, 2005). The green turtle (Chelonia mydas) can only be captured accidentally in fishing nets in Southern Cameroon (Fretey, 2001), probably because it is immature even though results have not been confirmed.

The green turtle suffers from uncontrolled exploitation by the local 
population who consume the turtles captured in the fishing nets (Angoni \& Fretey, 2001), despite the fact that all species of marine turtle are classified as endangered on the IUCN Red list (UICN, 2000). But sea turtles are not yet classified into classes of protection by the Cameroonian legislation.

The aim of this study is to determine length ranges of marine turtles as well as age groups of marine turtle populations which frequent the Campo Ma'an Technical Operational Unit (UTO) coastal zone, study their dispersal, identify threats and finally propose conservation measures for this species along the Cameroon coastline.

\section{MATERIALS AND METHODS}

Identification of green turtles by their scales

At the end of each laying season (April), between 1998 and 2005, a research team visited the 10 principal villages separating Kribi from Campo $(75 \mathrm{~km})$.

Carapaces recorded in various households or while on exhibit along the road were identified and measured including curved carapace length (CCL) and Curved Carapace width $(\mathrm{CCW})$.

\section{Local dispersal and migratory behaviour}

Captured individuals in fishing nets were tagged and released. Tagged turtles were recorded in order to assess their degree of local dispersal and migratory behaviour.

All recaptured turtles were identified by their tag numbers, and the location and the date of the initial tagging as well as the location and the date of recapture were registered (Biometric data; CCL and $\mathrm{CCW}$ ).

The tagging method consisted of placing a Monel tag model ECO 1105 (ECO=ECOFAC), F 729, (F=France) BJ 0485 (BJ=Benin) on the posterior edge of each of the anterior flippers of the animal.

To assess local dispersal and migratory behaviour of tagged turtles, all tagging data were linked to a regional network ("KUDU", for the Atlantic coast of Africa, active network of the CMS Memorandum of Abidjan), as well as to a sub regional database Marine Turtle Protection in Central Africa (PROTOMAC) for the Central African region, which host sea turtle tagging records and facilitate information sharing among partners and the exchange of tag recapture data.

\section{RESULTS}

A total of 209 individuals were measured and recorded, exhibiting a size class from $15-20 \mathrm{~cm}$ CCL to a maximum of $95-100$ $\mathrm{cm}$, with a modal class of 45-50 cm CCL.

We noticed that individuals less than $35-40 \mathrm{~cm}$ CCL were rare $(\mathrm{n}=06)$ as well as those above $65-70 \mathrm{~cm}$ CCL $(n=05)$. These results may indicate that the Campo Ma'an coast primarily represents a juvenile foraging habitat, while nesting habitats are absent and adults rare. For the 209 individuals observed, the average CCL was 50, $29 \mathrm{~cm}$ (range 19, 5 $\mathrm{cm}-100 \mathrm{~cm}$; SD 21, $02 \mathrm{~cm}$ ) and the average $\mathrm{CCW}$ was 49, $99 \mathrm{~cm}$ (range 17, $5 \mathrm{~cm}-98,5$ cm; SD 19, $64 \mathrm{~cm}$ ).

\section{Dispersal and migrations}

A total of 132 green turtles were tagged and released in order to follow their dispersal along the Campo Ma'an coastline.

Between 1999 and 2001, 18 of these tagged individuals were recaptured. Among them, 14 were recaptured in the vicinity of their release sites. At a distance of about $1 \mathrm{~km}$, 10 animals were recaptured between the first and ninth months of the first release and recapture date noted. Two animals moved an average straight line distance of $2 \mathrm{~km}$, one after 19 months and the other after 1 month. Two other turtles tagged with numbers ECO1205 and F729 in Lolabe (near Campo in the South of Cameroon) were recaptured in Kribi in the north. These two turtles had moved a distance of $30 \mathrm{~km}$ northward. 
A juvenile green turtle was recaptured in Equatorial Guinea to the south of Cameroon; ECO1129 was tagged on 21/01/99 in Ngoye (Kribi), and was recaptured nesting in the beach in Bata, (Equatorial Guinea) in 2001 (two years later), with a straight line distance of $200 \mathrm{~km}$.
The relatively close zones of recapture in relation to the time interval between the capture, tagging, release and recapture (Fig. 4) show that Chelonia mydas species migrate short distances on the Cameroon coastline.

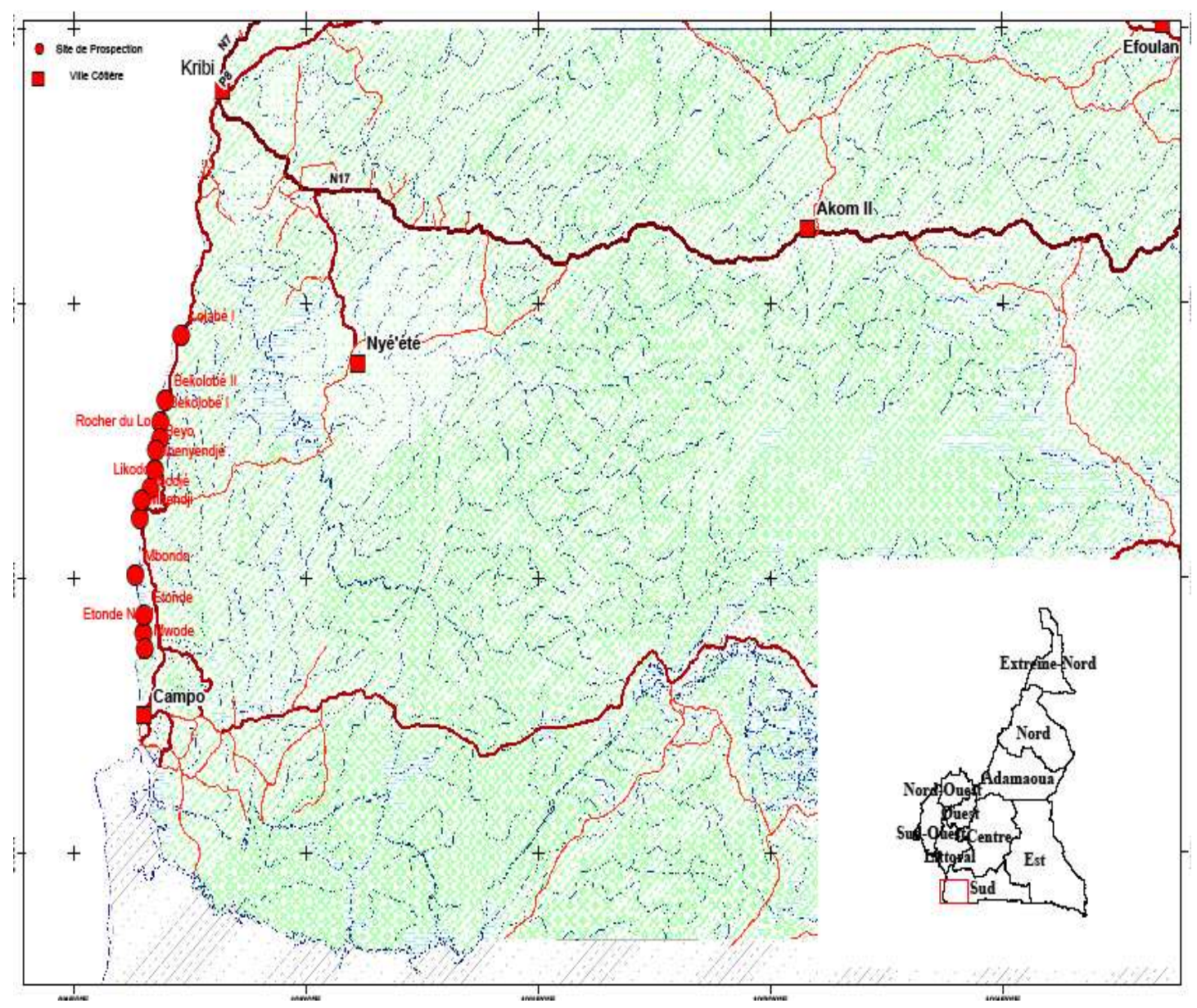

Figure 1: Campo Ma'an coastline study site. 


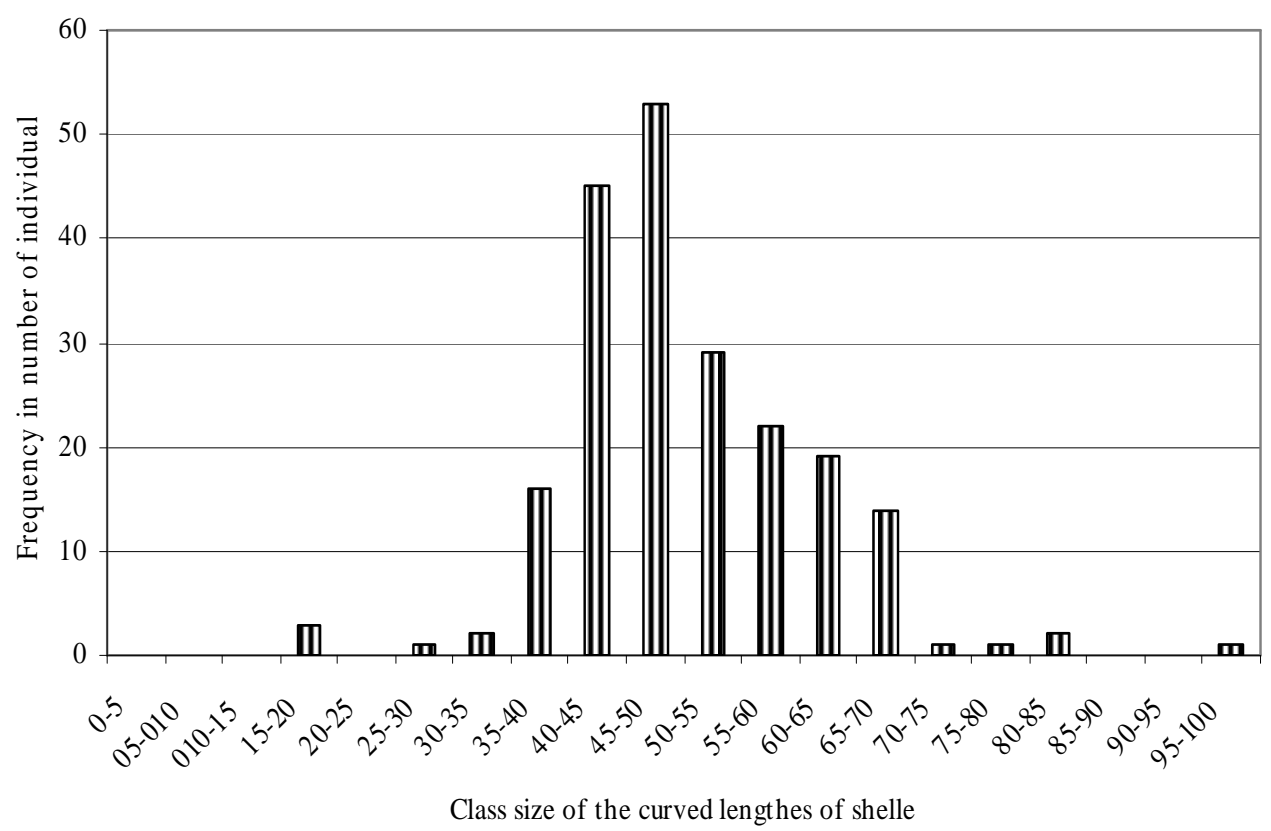

Figure 2: Size class of curved shell lenth $(\mathrm{cm})$.

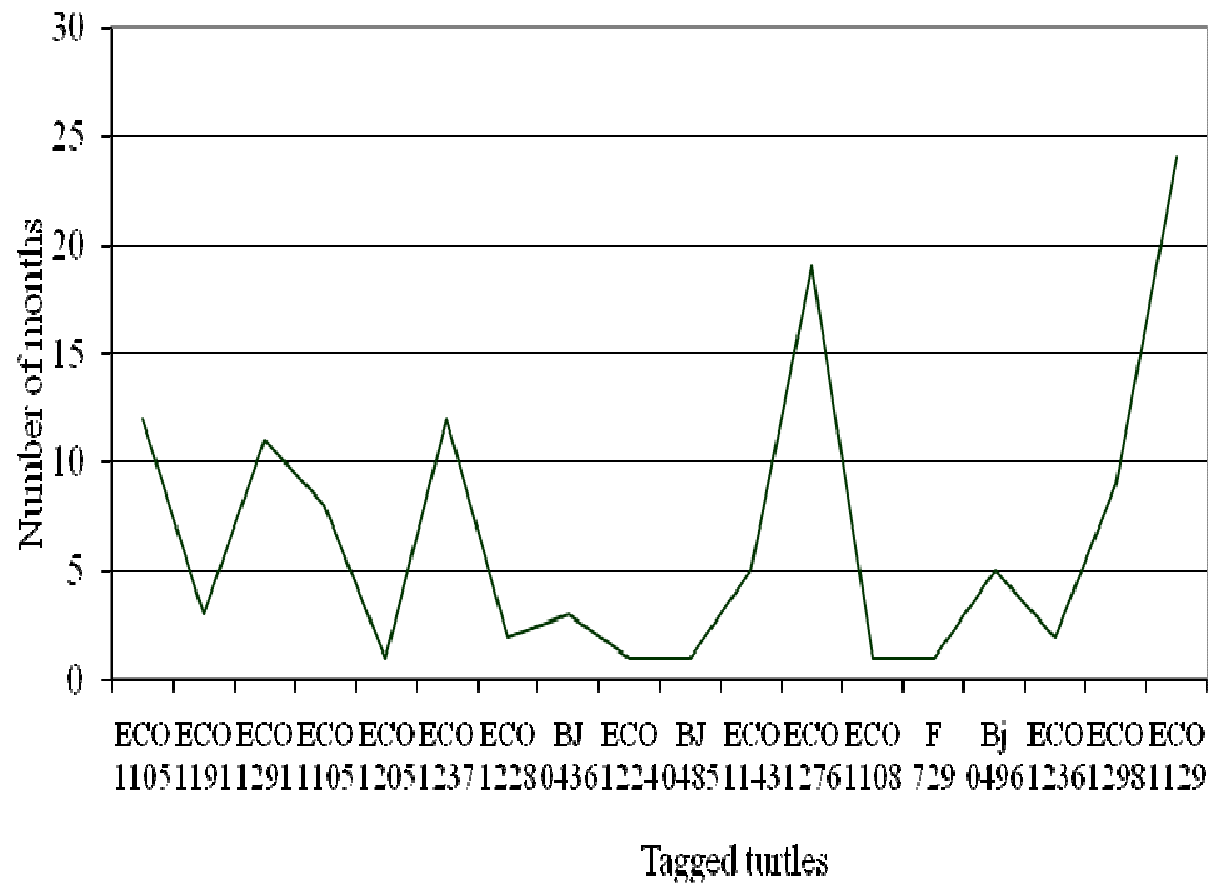

Figure 3: Number of months done by tagged turtles between the released and the recaptured point. 
A. HYACINTHE et al. / Int. J. Biol. Chem. Sci. 6(2): 641-649, 2012

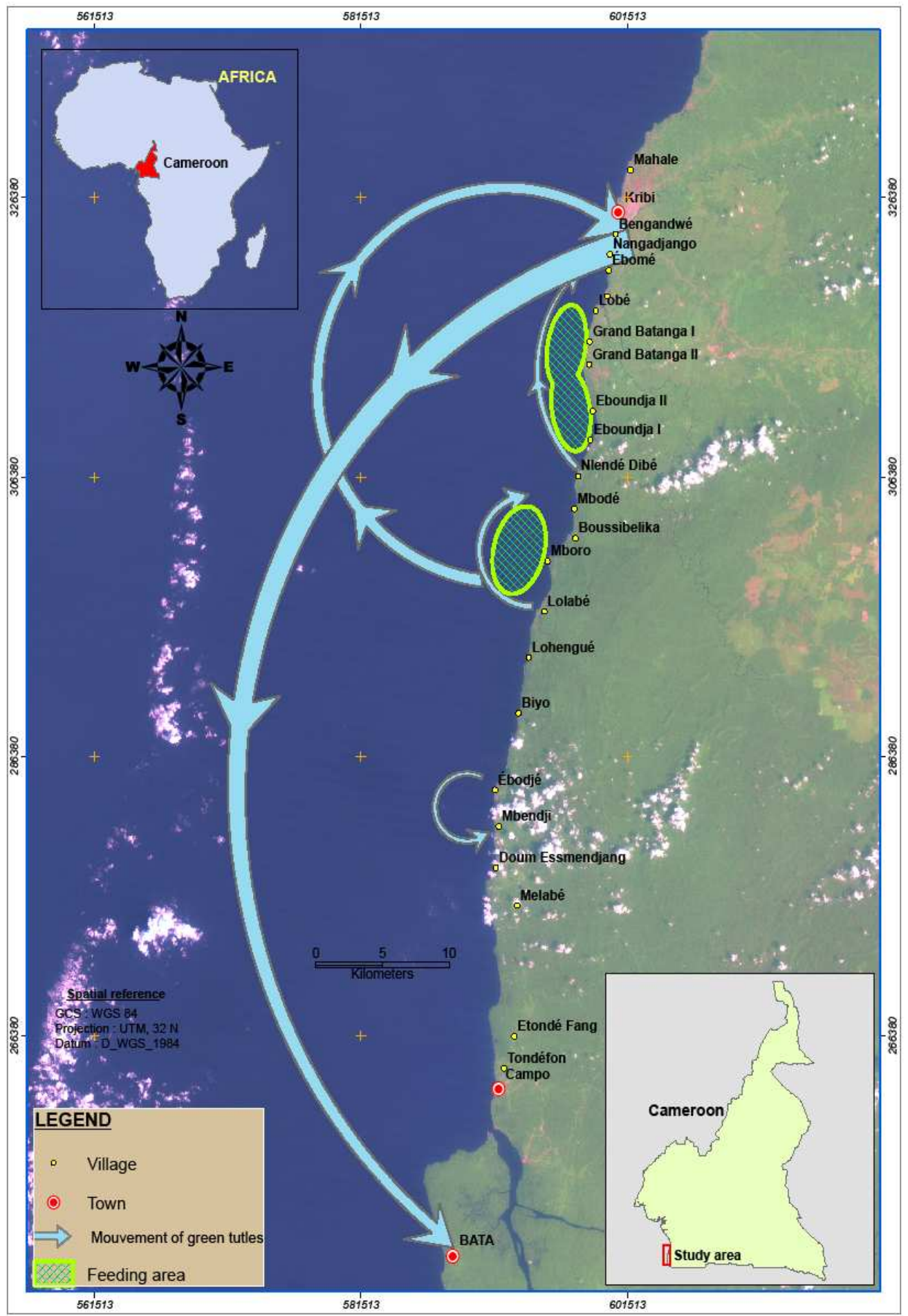

Figure 4: Movement $(\mathrm{km})$ of tagged Chelonia mydas in the Campo Ma'an coasline. 
A. HYACINTHE et al. / Int. J. Biol. Chem. Sci. 6(2): 641-649, 2012

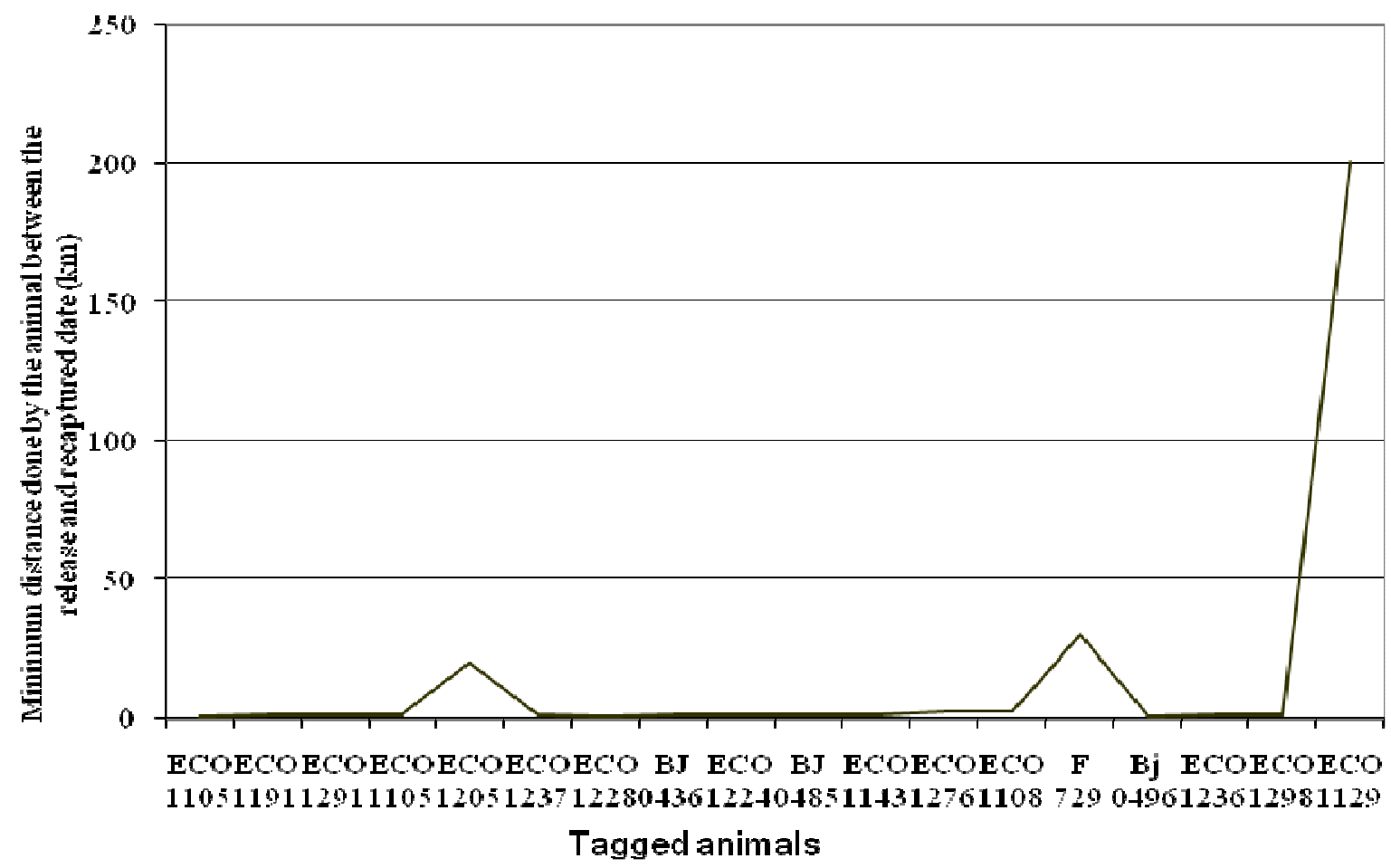

Figure 5: Movement $(\mathrm{km})$ of tagged Chelonia mydas in the Campo Ma'an coasline. 
A. HYACINTHE et al. / Int. J. Biol. Chem. Sci. 6(2): 641-649, 2012

Table 1: Date and location of initial capture and recapture of Chelonia mydas, between 1999 and 2001.

\begin{tabular}{|c|c|c|c|c|c|c|}
\hline \multirow[t]{2}{*}{ Left Tag } & \multicolumn{2}{|c|}{ First tagged } & \multicolumn{2}{|c|}{ Recaptured } & \multirow{2}{*}{$\begin{array}{l}\text { Days between first } \\
\text { release and recapture }\end{array}$} & \multirow{2}{*}{$\begin{array}{c}\text { Minimum distance } \\
\text { travelled }\end{array}$} \\
\hline & Date & Location & Date & Location & & \\
\hline ECO 1105 & $24 / 03 / 00$ & Elabe (Kribi) & $12 / 03 / 01$ & Elabe (Kribi) & 12 months & 500 meters \\
\hline ECO 1191 & $09 / 12 / 99$ & Mahalet (Kribi) & $07 / 03 / 00$ & Elabe (Kribi) & 3 months & $1 \mathrm{~km}$ \\
\hline ECO 1291 & 07/03/00 & Mahalet (Kribi) & $27 / 02 / 01$ & Elabe (Kribi) & 11 months & $1 \mathrm{~km}$ \\
\hline ECO 1105 & $12 / 03 / 00$ & Elabe (Kribi) & $29 / 01 / 01$ & Ngoye (Kribi) & 8 months & $1 \mathrm{~km}$ \\
\hline ECO 1205 & $16 / 10 / 00$ & Lolabe (Campo) & $20 / 11 / 00$ & Ebome (Kribi) & 1 month & $20 \mathrm{~km}$ \\
\hline ECO 1237 & $06 / 12 / 00$ & Elabe (Kribi) & $18 / 12 / 00$ & Elabe (Kribi) & 12 days & $1 \mathrm{~km}$ \\
\hline ECO 1228 & $21 / 11 / 00$ & Ngoye (Kribi) & $18 / 01 / 01$ & Wamie (Kribi) & 2 month & $500 \mathrm{~m}$ \\
\hline BJ 0436 & $16 / 02 / 01$ & Nziou (Kribi) & $18 / 05 / 01$ & Elabe (Kribi) & 3 months & $1 \mathrm{~km}$ \\
\hline ECO 1224 & $20 / 11 / 00$ & Ngoye (Kribi) & $04 / 12 / 00$ & Elabe (Kribi) & 1 month & $1 \mathrm{~km}$ \\
\hline BJ 0485 & $22 / 03 / 01$ & Mahalet (Kribi) & $09 / 04 / 01$ & Ngoye (Kribi) & 1 month & $1 \mathrm{~km}$ \\
\hline ECO 1143 & $15 / 03 / 00$ & Elabe (Kribi) & $20 / 03 / 00$ & Mahalet (Kribi) & 5 days & $1 \mathrm{~km}$ \\
\hline ECO 1276 & 07/03/00 & Mahalet (Kribi) & $26 / 03 / 00$ & Elabe (Kribi) & 19 days & $2 \mathrm{~km}$ \\
\hline ECO 1108 & $31 / 03 / 00$ & Elabe (Kribi) & $24 / 04 / 00$ & Ngoye (Kribi) & 1 month & $2 \mathrm{~km}$ \\
\hline F 729 & 03/10/01 & Lolabe (Campo) & $23 / 11 / 01$ & Nziou (Kribi) & 1 month & $30 \mathrm{~km}$ \\
\hline Bj 0496 & $11 / 05 / 01$ & Nlende & 6/09/01 & Nlende & 5 months & $500 \mathrm{~m}$ \\
\hline ECO 1236 & $04 / 12 / 00$ & Elabe (Kribi) & $05 / 02 / 01$ & Kribi & 2 months & $1 \mathrm{~km}$ \\
\hline ECO 1298 & 09/02/01 & Elabe (Kribi) & $26 / 11 / 01$ & Elabe (Kribi) & 9 months & $1 \mathrm{~km}$ \\
\hline ECO 1129 & 21/09/99 & Ngoye (Kribi) & 2001 & $\begin{array}{c}\text { Bata (Equat. } \\
\text { Guinea) }\end{array}$ & 2 years & $200 \mathrm{~km}$ \\
\hline
\end{tabular}




\section{DISCUSSION}

Chatelard and Roudgé (1994, cit. in Fretey 1998) indicated the presence of young individuals of Chelonia mydas at sea in Bibamboué, Ngoye and Kribi, in the southern region of Cameroon and suggested that adults may also be present. Fretey (1998) indicates that nesting habitat for this species is rare in Cameroon and insignificant with respect to the nesting frequency in Bioko (Equatorial Guinea).

During this study, 209 individuals of green turtle were observed in the sea, mostly captured in fishing nets. Nesting is still not confirmed in the coastal zone of the Campo Ma'an TOU.

Few adults were recorded (59 individuals). The mean curved carapace length is $50.29 \mathrm{~cm}$, indicating that the population consists primarily of immature and not reproductive adults. Observations on the reproductive biology of green sea turtles hatched and raised under farm conditions suggests that the minimum age of sexual maturity is eight to nine years (Delcroix \& al., 1980). At this sexual maturity age, the carapace length is about 65 to $69 \mathrm{~cm}$ (Bjorndal and Zug, 1995).

In fact, the nesting population of southern Bioko is the most significant in the region (Garcia, 1996), with an average CCL of approximately $100 \mathrm{~cm}$ (Fretey, 2001). Other nesting sites in the region which take place between October and January include Sao Tome and Principe (Loveridge and William, 1957) and Congo (Mbungu, 2009). But nesting sites are rare in Gabon (Fretey and Girardin, 1989) and suspected in the Democratic Republic of Congo (Gawler and Agardy, 1994). Few immature turtles have been seen in Gabon (Sounguet \& Christy, 1997).

The species is herbivorous, feeding on algae and other marine plants (Meylan, 1995; Bjorndal and Zug, 1995). Although not yet identified taxonomically, the presence of such flora and of juvenile green turtles in rocky zones throughout the year indicates that the coastline of the Campo Ma'an TOU is a feeding area. It is not clear whether adults also forage in the area (but they are recorded less frequently) or whether they occasionally use the area as migratory habitat during transits to nesting sites (Fretey, 2001).

The average minimum distance between release and recapture point was 0,5 $\mathrm{Km}$ in one year, (while individuals of Chelonia mydas tagged in several localities in the Indian Ocean were recaptured in Madagascar and Mozambique at distances of 320 and $1400 \mathrm{~km}$ (Meylan, 1995). The markings on C. Mydas put to evidence the periodic migrations between the laying site and the feeding site indicating that the juveniles remain largely sedentary in the area with a residence time of at least 4 months. Tagging has also indicated that most Hawaiian green turtles seem to settle at a specific foraging ground and leave only to reproduce (Anonymous, 1992). Our observations strongly support this theory since we have seen the same core group of animals every year since 1989 .

\section{Conclusion}

This inventory and migration study of sea turtles showed that the coastal zone of the Campo-Ma'an TOU, although partially subjected to human activities, is a significant developmental habitat for Chelonia mydas. The species is not confirmed to nest on the Campo Ma'an coastline. Green turtles are regularly seen not far from the coastline and are often captured accidentally by fishermen. This population consists mainly of young individuals. The area, rich in algae, probably represents a feeding area for immature green turtles. Therefore, it becomes urgent to establish concrete conservation initiatives focused on sea turtle habitat in the CampoMa'an area. This will also require the reinforcement of legislation, the involvement of the local populations and the establishment of a marine protected area in the Kribi Campo coastal zone. 


\section{REFERENCES}

Angoni H. 2005. Biologie et écologie des tortues marines en rapport avec les écosystèmes côtiers. Conservation et aménagement. Thèse de Doctorat Université de Yaoundé I, Cameroun, 93 p.

Angoni H, Fretey J. 2001. Suivi et conservation des tortues marines dans l'UTO Campo-Ma'an.Rapport de phase I. Projet Campo-Ma'an.

Annonymous 1992. The Hawaiian Green Turtle (Chelonia mydas) U.S. Department of Commerce, National Oceaonographic and Atmosphere Interim Recovery Plan for Hawaiian Sea Turtles, National Marine Fisheries Service, 1992, National Marine Fisheries Service, NOAA-TMNMFS-SWFC-7, 1980.

Bjorndal KA, Zug GR. 1995 Growth and age of sea turtles. In Biology and Conservation of Sea Turtles (Revised edn), Bjorndal KA (ed). Smithsonian Institution Press: Washington, DC; 599600.

Delcroix E, Godfrey MH, Mazeas. 2008. Postnesting migrations of green turtles (Chelonia mydas) from the archipelago of Guadeloupe (FWI) revealed by satellite tracking. Proceedings of the 27th Annual Symposium on Sea Turtle Biology and Conservation, Rees AF, Frick M, Panagopoulou A, Williams K (Comps.). NOAA Tech Memo NMFS-SEFSC-569; 38-39.

Fretey J. 1998. Statut des tortues marines en Afrique Centrale-Afrique de l'Ouest. Le Cameroun. Rapport UICN. 152 p.

Fretey J. 1999. Suivi et conservation des tortues marines dans la réserve de
Campo-Ma'an. Rapport du projet CampoMa'an. 40 p.

Fretey J. 2001. Biogéographie et conservation des tortues marines de la côte atlantique d'Afrique. CMS Technical series publication. No $6.428 \mathrm{p}$.

Fretey, Girardin. 1989. Données préliminaires sur les tortues marines au Gabon. C. R. Soc. Biogéogr. 65(1): 39-57.

Garcia JE. 1996. Conservation des tortues marines sur l'île de Bioko, en Guinée Equatoriale. Canopée 8: 7.

Gawler M , Agardy T. 1994. Developing WWF priorities for marines conservation in the Africa and Madagascar Region. WWF Africa and Madagascar Subcomm. and WWF Marine Advisory Group, $67 \mathrm{p}$.

IUCN 2000. Red list of threatened species. Convention Monitoring Center, IUCN: Cambridge, Royaume Uni, $27 \mathrm{p}$.

Loveridge A, William EE. 1957. Revision of the African tortoises and turtles of suborder Cryptodira. Bull. museum 115(6): 163-557.

Meylan PA. 1995. Sea turtle migrationevidence from tag returns. In Biology and Conservation of Sea Turtles (Revised edn), Bjorndal KA (ed). Smithsonian Institution Press: Washington, DC; 91100.

Mbungu SD. 2009. Evaluation des impacts des menaces anthropiques subies par les tortues marines nidifiant au littoral de Muanda au Bas-Congo/RDC (Monitoring de trois saisons de ponte).

Sounguet GP, Christy P. 1997. Protection et conservation des zones de ponte des tortues marines à la pointe de Pongara. Rapport miméogr. A.S. Monitoring of Green turtle in Cameroon. 